\title{
MENTORING SEBAGAI SUATU INOVASI DALAM PENINGKATAN KINERJA
}

\author{
Zul Anwar ${ }^{1}$, Hastuti Diah Ikawati ${ }^{2}$, Syarifah $^{3}$ \\ IKIP Mataram, ${ }^{1,2}$, IKIP PGRI Banjarmasin ${ }^{3}$ \\ zulanwar@ikipmataram.ac.id ${ }^{1}$
}

\begin{abstract}
ABSTRAK
Tujuan penelitian ini adalah untuk melihat mentoring sebagai suatu inovasi dalam peningkatan kinerja. Jenis penelitian ini adalah penelitian kepustakaan. Teknik pengumpulan data dilakukan dengan metode dokumentasi yaitu membaca setiap informasi yang ada hubungan dengan kajian. Data yang terkumpul dari hasil bacaan kemudian dianalisis dengan cara memilih materi-materi yang sesuai atau masih berkaitan dengan kajian. Berdasarkan hasil analisis data, hasil proses mentoring adalah disengaja, tidak terjadi secara kebetulan. Kunci untuk memastikan hasil yang diinginkan dan kelangsungan proses mentoring adalah dengan menggunakan semua praktik terbaik dari teknologi kinerja manusia dalam tahap penilaian kebutuhan, perencanaan, desain, implementasi, dan evaluasi. Mentoring harus terkait erat dengan misi, tujuan, dan strategi prioritas organisasi. Hanya mutu terpadu, yang mampu memfasilitasi proses terkait dengan misi saatini dan masa depan yang dapat diharapkan untuk menghadapi terpaan dari angin perubahan. Lingkungan berubah dengan cepat menuntut multi-terampil, pekerja fleksibel, dan tingkat penguasaan kompetensi inti. Sebuah proses mentoring penting untuk memfasilitasi peningkatan kinerja manusia. Dengan asumsi penting bahwa perilaku individu (mantees dan mentor) dapat diubah karena menyadari setiap individu wajib untuk terus menerus belajar (long life learner).
\end{abstract}

Kata Kunci: Mentoring, Peningkatan Kinerja, Inovasi

\begin{abstract}
Mentoring is a strategy to improve work performance within an organization. This type of research is literature research. Technique of collecting data is done by documentation method that is reading every information that there is relation with study. The data collected from reading results is then analyzed by selecting the appropriate materials or still related to the study. Based on the results of data analysis then synthesized and concluded to be a conclusion of the topic under study. The result of the mentoring process is intentional, does not happen by chance. The key to ensuring the desired outcomes and the sustainability of the mentoring process is to use all the best practices of human performance technology in the needs assessment, planning, design, implementation, and evaluation phase. Mentoring must be closely linked to the organization's mission, objectives, and strategy priorities. Only an integrated quality, capable of facilitating the process associated with current and future missions that can be
\end{abstract}


expected to deal with exposure to the winds of change. The rapidly changing environment demands multi-skilled, flexible workers, and the level of mastery of core competencies. A mentoring process is important to facilitate the improvement of human performance. With the important assumption that individual behavior (mantees and mentors) can be changed as it is aware of each individual is obliged to continuously learn (long life learner).

Keywords: Mentoring, Performance Improvement, Innovation

\section{PENDAHULUAN}

Dampak globalisasi telah membawa perubahan pada setiap bidang pekerjaan yang mengharuskan para pekerja untuk memiliki pengetahuan dan kompetensi untuk mempersiapkan diri sebagai masyarakat kompetitif. Kurangnya persiapan pengetahuan dan kompetensi telah diidentifikasi sebagai masalah di antara para pekerja. Untuk mengatasi kekurangan tersebut, artikel ini mengusulkan penggunaan hubungan mentoring sebagai strategi untuk peningkatan kinerja dimana telah terbukti untuk bekerja di semua jenis organisasi. Sejak tahun 1970, beberapa peneliti dan praktisi telah melacak hasil untuk menunjukkan nilai tambah kompetensi yang lebih besar, kepercayaan diri yang kuat, dan loyalitas peserta yang terlibat dalam proses mentoring (Murray, 2006).

Artikel ini mengkaji faktor kunci keberhasilan untuk proses mentoring yang efektif. Selain itu, juga akan menjelaskan beberapa format kontemporer interaksi masyarakat yang disebut mentoring. Dimulai dengan definisi mentoring, desain proses mentoring difasilitasi pertama, pada akhir tahun 1960, kamus populer menunjukkan mentor hanya sebagai kata benda. Merujuk pada kamus online terbaru, definisi umum yaitu seseorang yang lebih tua dan lebih berpengalaman, yang memberikan nasihat dan dukungan untuk, dan mengawasi dan mendorong kemajuan, lebih muda, orang yang kurang berpengalaman (Kamus Inggris Dunia Encarta, 1999).

Definisi kedua mengakui penggunaan kontemporer dengan definisi kata kerja bertindak sebagai mentor untuk seseorang, terutama seorang rekan junior (Kamus Inggris DuniaEncarta, 1999). Definisi ini sudah usang dalam praktek mentoring saat ini, di mana mentor tidak selalu lebih tua, senior, dan anak didik tidak selalu muda, junior. Beberapa hasil mentoring yang paling efektif diperoleh dalam pasangan-pasangan yang sejawat dengan seperangkat keahlian yang berbeda. Di mana mentor adalah baru bagi organisasi, muda, dan membawa keterampilan inovatif yang dibutuhkan dalam organisasi.Sebagaimana salah satu contoh program mentoring teman sebaya yang telah dilaksanakan di Universitas Zaragoza selama tahun akademik 2012-2013 telah diterima baik oleh tim manajemen universitas dan telah mencapai keterlibatan mentor mahasiswa yang luar biasa dalam mendukung siswa baru. Hal ini dicapai melalui penerapan model 
organisasi yang sesuai dan metode kegiatan penilaian yang obyektif dan transparan (Loyo, et al., 2015).

\section{METODE PENELITIAN}

Jenis penelitian ini adalah penelitian kepustakaan. Metode ini digunakan untuk mendapatkan pengetahuan berupa informasi tentang topik yang dikaji. Teknik pengumpulan data dilakukan dengan metode dokumentasi yaitu membaca setiap informasi yang ada hubungan dengan kajian. Data yang terkumpul dari hasil bacaan kemudian dianalisis dengan cara memilih materi-materi yang sesuai atau masih berkaitan dengan kajian. Berdasarkan hasil analisis data kemudian disintesis dan disimpulkan sehingga menjadi satu kesimpulan dari topik yang diteliti.

\section{HASIL DAN PEMBAHASAN}

Dalam upaya untuk membawa beberapa kejelasan dasar untuk diskusi dan contoh yang digunakan dalam artikel ini, akan dimulai dengan konsep dasar dan definisi dari istilah. Ketika berhubungan dengan contoh dari proses mentoring organisasi, maka akan digunakan istilah yang digunakan oleh peserta dalam organisasi tertentu. Ketika berjuang untuk kejelasan dan pemahaman bersama, akan digunakan istilah yang paling jelas yaitu istilah populer dan sering digunakan untuk membedakan peran dan fungsi.

Definisi kerja mentoring adalah, sebuah pasangan yang disengaja dari orang yang lebih terampil atau berpengalaman dengan orang kurang ahli atau lebihkurangberpengalaman, dengan disepakati memiliki tujuan orang yang ahli lebih rendah tumbuh dan mengembangkan kompetensi spesifik (Murray, 1991). Seringkali ada banyak formalitas dan birokrasi diterapkan pada sumber daya manusia dan program personel. Untuk menghindari hal ini dengan proses mentoring, Murray memilih istilah difasilitasi, dan didefinisikan sebagai struktur dan serangkaian proses yang dirancang untuk menciptakan hubungan mentoring yang efektif, memandu perubahan perilaku yang diinginkan dari pihak yang terlibat, dan mengevaluasi hasil untuk anak didik, mentor, dan organisasi (Murray, 1991).

Majalah pelatihan melaporkan bahwa 77 persen dari "Top 100" perusahaan memiliki program mentoring formal. Artikel itu mengutip berbagai penilaian format dan desain proses mentoring perusahaan. Beberapa ditargetkan untuk kelompok tertentu dan beberapa yang terbuka untuk semua karyawan.

Sebagian besar dari pengalaman mentoring dijelaskan dalam hal positif oleh kedua anak didik dan mentor. Kadang-kadang, kita mendengar dan membaca tentang beberapa pengalaman yang tidak menyenangkan untuk anak didik dan beberapa ada yang kurang memberi penghargaan untuk mentor. Pengalamanpengalaman negatif yang paling sering dilaporkan dari mentoring hubungan yang 
formal, biasanya dengan tidak ada diskusi tertentu atau kesepakatan bersama tentang harapan kedua mitra.

Mentor bidang akademik juga menjunjukkan digunakan sebagai jalan untuk meingkatkan prestasi dan kesuksesan peserta didik. Dicontohkan dalam proses penyelesaian tugas akhir mahasiswa memerlukan mentor atau pembimbing. Ini menunjukkan bahwa mentor senantiasa dibutuhkan dalam setiap sisi kehidupan akademik, (Ruth Enid Zambrana, 2015).

\section{Tabel.1}

Faktor-FaktorKunci Suksesuntuk Mentoring Informal Versus difasilitasi

\begin{tabular}{|c|c|c|}
\hline Faktor Kunci Sukses & Pembimbingan Informal & Pembimbingan difasilitasi \\
\hline tujuan bisnis & $\begin{array}{l}\text { Pembimbingan tidak terikat } \\
\text { dengan tujuan; } \\
\text { hubungan tidak dilacak. }\end{array}$ & $\begin{array}{l}\text { Pembimbingan terkait dengan } \\
\text { inisiatif bisnis yang ada; Hasil } \\
\text { diukur. }\end{array}$ \\
\hline $\begin{array}{l}\text { Kepemilikaninternal } \\
\text { program }\end{array}$ & $\begin{array}{l}\text { Kepemilikan tidak jelas; ada } \\
\text { sedikit dukungan atau } \\
\text { koordinasi. }\end{array}$ & $\begin{array}{l}\text { Kepemilikan oleh koordinator } \\
\text { proyek yang terampil dalam } \\
\text { komunikasi, negosiasi, mediasi, } \\
\text { dan evaluasi. }\end{array}$ \\
\hline $\begin{array}{l}\text { Pengembangan keterampilan } \\
\text { dan perilaku anak didik }\end{array}$ & $\begin{array}{l}\text { Mentoring seringkali adalah } \\
\text { sebuah hubungan yang lebih } \\
\text { umum, dengan fokus yang } \\
\text { kurang spesifik. }\end{array}$ & $\begin{array}{l}\text { Pembimbingan difokuskan pada } \\
\text { pengembangan keterampilan } \\
\text { dan transfer pengalaman; juga } \\
\text { terkait dengan rencana } \\
\text { pengembangan individu. }\end{array}$ \\
\hline $\begin{array}{l}\text { Orientasikomprehensifanak } \\
\text { didikdanmentor }\end{array}$ & $\begin{array}{l}\text { Tidak adaorientasi; } \\
\text { pelatihanumumtidakterkait } \\
\text { dengankebutuhan } \\
\text { spesifikdari pasangan. }\end{array}$ & $\begin{array}{l}\text { Ada orientasi komprehensif } \\
\text { untuk fokus pada peran, faktor } \\
\text { kunci sukses, proses mentoring, } \\
\text { dan tujuan. }\end{array}$ \\
\hline $\begin{array}{l}\text { Dukungan yang } \\
\text { berkelanjutanuntuk } \\
\text { pasanganmentoring }\end{array}$ & $\begin{array}{l}\text { Tidak ada dukungan } \\
\text { terstruktur. }\end{array}$ & $\begin{array}{l}\text { Facilitated Mentoring } \\
\text { Programme (FMP) koordinator } \\
\text { yang memfasilitasi, memediasi, } \\
\text { dan menyediakan sumber daya } \\
\text { yang diperlukan. }\end{array}$ \\
\hline Hasildiukur & $\begin{array}{l}\text { Ada sedikit atau tidak ada } \\
\text { tindak lanjut, dengan } \\
\text { sebagian besar data bersifat } \\
\text { anekdot. }\end{array}$ & $\begin{array}{l}\text { Acuan } \\
\text { dasarditetapkanselamapenilaian } \\
\text { kebutuhan; evaluasi periodik } \\
\text { mengukur } \\
\text { hasil; hasil terkait dengantujuan } \\
\text { bisnis. }\end{array}$ \\
\hline
\end{tabular}

Semakin banyak manajer dan pemimpin yang beralih kementoring sebagai strategi untuk meningkatkan kinerja. Tenaga kerja yang sangat kompeten 
dipandang sebagai keunggulan kompetitif yang paling menjanjikan ketika teknologi telah merambah ke berbagai level pekerjaan. Kisaran luas memasuki tingkat pengetahuan dan keterampilan pekerja untuk membuat pembelajaran kelaskadang-kadang tidak efektif dan tidak efisien. Waktu yang terbatas untuk tugas-tugas segudang di pekerjaan bagi setiap pekerja membuatnya penting untuk setiap pengalaman belajar yang akan difokuskan pada kebutuhan individu tertentu dan kesenjangan keterampilan.

Beberapa organisasisaat ini menggambarkan diri mereka sebagai "organisasi pembelajaran" dengan semangat yang sama bahwa banyak diungkapkan ketika menggambarkan diri merekasebagai "organisasi mutu terpadu". Sebuah proses mentoring difasilitasi, diintegrasikan ke dalam budaya organisasi dan selaras dengan proses manusia lainnya dalam peningkatan kinerja, dapat menciptakan iklim belajar yang terus menerus sehingga mendapatkan deskripsi "organisasi pembelajaran."

Dampak dari proses mentoring dapat diukur dengan melacak trenditujuan, kebutuhan, dan peluang organisasi. Sebagai contoh, sebuah organisasi memiliki tujuan meningkatkan keuntungan melalui penjualan. Sebuah proses mentoring dilaksanakan untuk mempersingkat waktu siklus untuk tenaga penjualan untuk memenuhi target penjualan. Penjualyang sedang dilatih oleh mentor meningkatkan penjualan mereka secara signifikan lebih dari penjual lain yang tidak memiliki mentor.

\section{Mentoring: Proses, Peran, dan Tugas}

Dalam praktek yang sangat baik saat ini dengan mentoring difasilitasi, pendampingan berjangka waktu menggambarkan proses yang sengaja berpasangan dua orang dengan keahlian dan pengalamannya dengan tujuan sharing keterampilan dan pengalaman dari orang yang membimbing mereka kepada orang yang membutuhkan mereka. Mentor adalah peran yang diambil oleh seseorang yang bersedia untuk membantu orang lain belajar dan tumbuh dengan menyetujui untuk berinteraksi dengan orang ini untuk sharing pengalaman dan keterampilan. Mentor dapat melakukan beberapa tugas dalam proses interaksi mereka dengan anak didiknya.

Tugas peran ini mencakup tetapi tidak terbatas untuk bimbingan, pembinaan, mendengarkan, konseling, pengajaran, pemodelan, memberikan umpan balik, menunjukkan, memberikan informasi, memfasilitasi kinerja yang diinginkan, dan membimbing. Untuk memperjelas apa saja peran mentor yang sesuai dengan kebutuhan anak didik mereka, berikut ini ada contoh hasil penelitian yang dapat dirujuk untuk mengeksplorasi pemahaman tugas, peran, dan proses sebagai mentor berpengalaman. Penelitian tentang masyarakat belajar profesional (PLC), mentoringdan kepemimpinan ini menganalisis tanggapan tertulis dari 27 mentor berpengalaman yang beroperasi di beberapa peran yang bervariasi (misalnya, akademisi universitas, eksekutif sekolah, guru, belajar 
personil pendukung). Temuan menunjukkan bahwa PLC dapat memberikan perpanjangan profesional bagi guru yang ada dan yang mentoring dalam PLC dapat memiliki pengetahuan terlebih dahulu tentang praktik yang efektif. PLC dapat mencakup anggota staf lainnya dan stakeholder kunci (misalnya, guru preservice, pembantuguru) yang dapat berkontribusi pada pembelajaran dalam kelompok. Mentoring dan PLC sebagai strategi hemat biaya untuk memajukan pengetahuan profesional (Hudson, 2013).

\section{Evolusi dari Konsep Mentoring}

Prinsip-prinsip dan praktek pemodelan dan mentoring menjadi elemen kunci dalam kelangsungan seni, kerajinan, dan perdagangan dari zaman kuno. Dalam seni dan kerajinan gilda orang muda magang ke master yang dianggap sangat baik dalam perdagangan atau profesi (Murray, 1991, 2001). Master mengajarkan, melatih, dan membimbing pengembangan keterampilan dalam perdagangan atau seni. Untuk menjadi seorang guru, keterampilan magang ini telah dinilai dari contoh kerja, seperti lukisan, atau bahkan tapal kuda. Kata karya agung berasal dari contoh kerja terampil ini.

Gambaran tradisional mentor adalah seorang tua, layanan berdurasi panjang orang yang dipilih anak didiknya sendiri dan mengambil orang-orang yang beruntung tegas di bawah satu sayap untuk memandu pengembangan karir seumur hidup mereka. Gambaran ini akhirnya memudar. Kadang-kadang bahkan mungkin ada sisi gelap hubungan mentoring. Di beberapa kasus, mentor menggunakan anak didik untuk proyek-proyek pekerjaan, mengambil kredit untuk pekerjaan, kadang-kadang menyalahgunakan hubungan dari mitra mentoring.

Fleksibilitas adalah penting ketika tempat kerja meliputi orang-orang dari puluhan budaya yang berbeda. Memungkinkan sharing keterampilan yang diperlukandan pengalaman dalam proses mentoring difasilitasi dapat memperkuat fleksibilitas ini.

\section{Struktur yang berbeda dari Mentoring}

Banyak format dan struktur yang berbeda disebut "mentoring". Berikut dijelaskan secara singkat beberapa format dan struktur yang populer. Regu Oneto-One yang difasilitasi. Format ini telah teruji menjadi strategi efektif untuk efisiensi biaya untuk mentransfer keterampilan dan pengalaman. Idealnya, pelaksanaannya didasarkan pada kurangnya keterampilan atau pengalaman dari anak didik tersebut. Mentor adalah seseorang dengan tingkat penguasaan dalam keterampilan yang dibutuhkan dan pengalaman yang diinginkan.

Format mentoring ini dapat pula dicontohkan dari hasil penelitian di Prancis tentang kemungkinan menggunakan keterlibatan pengalaman pensiunan mengingat tingginya tingkat pendidikan dan kualifikasi profesional yang sudah dimilikinya (Artcer, 2015). 
Mentoring Memutar balikkan. Sebaliknya mentoring adalah istilah yang digunakan oleh beberapa perusahaan dan lembaga untuk menggambarkan proses memasangkan sebuah tingkat yang lebih rendah, kadang-kadang pekerja baru dengan eksekutif-tingkat yang lebih tinggi atau administrator. Tujuannya biasanya untuk memberikan kesempatan bagi senior untuk mendapatkan masukan langsung dari level dasar atau orang baru tersebut.

Mentoring Kelompok. Organisasi yang menggunakan apa yang mereka sebut "kelompok mentoring" yang mengutip kekurangan mentor sebagai alasan untuk membuat grup. Format ini juga dinamakan dengan peer mentoring atau bimbingan teman sebaya.

Mentoring Lingkaran. Mentoring lingkaran adalah istilah lain yang digunakan untuk proses kelompok. Biasanya peserta terdiri darisejumlah pekerja yang se-level yang datang bersama-sama secara berkala untuk sharing ide dan strategi. Dengan kondisi, ketika ada satu orang telah belajar dapat diteruskan ke orang lain, sehingga menghemat waktu belajar untuk beberapa trial-and-error.

Kesimpulannya, pasangan mentoring dapat berasal dari level atas, bawah, atau ke samping (peer) dalam beberapa format transfer ini mungkin terjadi. Di samping itu, tujuan mentoring sebagai sharing keterampilan dan pengalaman tetap sebagai kuncinya.

\section{SIMPULAN}

Setiap organisasi memiliki investasi besar dalam modal intelektual karyawan berpengalaman. Pengetahuan manajemen akan dituntut dari tim eksekutif perusahaan yang cerdas. Hasil proses mentoring adalah disengaja; mereka tidak terjadi secara kebetulan. Kunci untuk memastikan hasil yang diinginkan dan kelangsungan proses mentoring adalah dengan menggunakan semua praktik terbaik dari teknologi kinerja manusia dalam tahap penilaian kebutuhan, perencanaan, desain, implementasi, dan evaluasi. Mentoring harus terkait erat dengan misi, tujuan, dan strategi prioritas organisasi. Hanya mutu terpadu, yang mampu memfasilitasi proses terkait dengan misi saatini dan masa depan yang dapat diharapkan untuk menghadapi terpaan dari angin perubahan. Lingkungan berubah dengan cepat menuntut multi-terampil, pekerja fleksibel, dan tingkat penguasaan kompetensi inti. Sebuah proses mentoring penting untuk memfasilitasi peningkatan kinerja manusia. Dengan asumsi penting bahwa perilaku individu (mantees dan mentor) dapat diubah karena menyadari setiap individu wajib untuk terus menerus belajar (long life learner). 


\section{DAFTAR PUSTAKA}

Anne H \& Soukhanov. (1999). Encarta World English Dictioary. London: Bloomsbury

Artcer, T., Galiegue, X., \& Mondello, G. (2015). Mentoring as a Way of Forming and Effective Utilization of Manpower (the Experience of France). Procedia - Social and Behavioral Sciences, Vol. 166

Hudson, P., Hudson, S., Gray, B., \& Bloxham, R. (2013). Learning About Being Effective Mentors: Professional Learning Communities and Mentoring. Procedia - Social and Behavioral Sciences, Vol. 93, 21 Oktober 2013.

Loyo, J., M., Y., Ascaso, M., D., C., \& Martín, J., P., (2015). Peer mentoring at the university level: the importance of organization. Procedia - Social and Behavioral Sciences, Vol. 196, 8 July 2015.

Murray, M. (2006). Innovations in Performance Improvement with Mentoring. Handbook of Human Performance Technology:Principles, Practices, and Potential, Third Edition. (Chapter: 19, Hal.: 455-477).

Ruth Enid Zambrana, Rashawn Ray, Michelle M. Espino. (2015). Dont Leave Us Behind: The Importance of Mentoring for Underrepresented Minority Faculty, American Educational Research Journal, 52(1) 